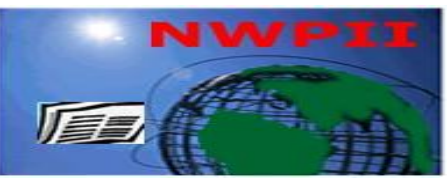

American Journal of Biomedical Sciences

ISSN: 1937-9080

nwpii.com/ajbms

\title{
Beneficial Effect of Tea on Human Health
}

\author{
Aleksander Yashin ${ }^{1}$, Yakov Yashin ${ }^{1}$ and Boris Nemzer ${ }^{2} *$ \\ ${ }^{1}$ InterLab, Inc., 12a Selskohozyaistvennaya Street, Moscow 129226 Russia \\ ${ }^{2}$ VDF FutureCeuticals, Inc., 2692 North State Rt. 1-17, Momence, IL 60954 USA, University of Illinois at Urbana- \\ Champaign, Department of Food Science and Human Nutrition, Urbana, IL 61801 USA \\ *Corresponding Author \\ Boris Nemzer \\ Director of Research and Development \\ FutureCeuticals, Inc. \\ Momence, IL 60954 USA \\ Email: bnemzer@futureceuticals.com
}

Received: 20 August 2013; | Revised: 5 November 2013; | Accepted: 16 November 2013

\begin{abstract}
Tea, with its 5,000-year history, is one of the most popular beverages in the world. According to various estimates, over 4 billion people consume tea. This number has increased in recent years due to the widespread marketing of cold tea-based beverages. During the first millennium tea was primarily considered to be medicine rather than an ordinary drink. Over the last few years a large number of epidemiological studies have conclusively proven that tea is beneficial for people with cardiovascular and neurodegenerative diseases, and cancers. Tea catechins are included in numerous dietary supplements and medicinal products. This review summarizes scientific information related to the effects of tea on human health which have been published in the last decade.
\end{abstract}

Keywords: green tea; polyphenols; catechins, free radicals, activity, human health.

\section{Introduction}

In ancient China, tea was used as a medicine for many centuries before it was eventually used as a beverage. In recent decades, numerous studies conducted in several countries of Eastern Europe, Africa, and America have shown that tea-especially green tea-has potent healthimproving effects.

Tea is a health beneficial nutraceutical. This is confirmed by millions of people who have been consuming tea for five thousand years in China and for over 400 years for the rest of the world. Today, more than 4 billion people in the world drink tea. Many research articles, reviews and books describe the effects of tea on human health [1-37]. In the past 20 years, clinical laboratory research and epidemiological review of data for both animals and humans have convincingly shown that green tea catechins reduce the risk of cardiovascular diseases and cancers. The positive effect of catechins is associated with their high antioxidant activity. Catechins can inhibit cell 
proliferation, regulate carcinogen-metabolizing enzymes, and induce apoptosis [30].

\section{Radical Capturing Activities}

It has been experimentally shown that the beneficial effects of green tea polyphenols are associated with the capturing (neutralization) of free radicals. One study explored the ability of green tea catechins to capture free radicals, such as hydroxyl radicals, superoxide radical, lipid free radicals, and singlet oxygen [38]. The concentration of free radicals was determined by electron spin resonance, a direct and reliable method.

Free radicals were generated by established techniques, in particular hydroxyl radicals generated by Fenton reaction $\left(0.1 \% \mathrm{H}_{2} \mathrm{O}_{2}+\mathrm{Fe}^{2+} \rightarrow \mathrm{Fe}^{3+}+\mathrm{OH}^{\circ}+\mathrm{RH}\right)$.

Epicatechin gallate (ECG) at concentrations of $0.75 \mu \mathrm{M}$ decreased the amount of hydroxyl radicals by $46.5 \%$. Epicatechin (EC) at low concentrations reduced the amount of hydroxyl radicals by $19.1 \%$. At these very low concentrations, epigallocatechin gallate (EGCG) and epigallocatechin (EGC) did not neutralize hydroxyl radicals at all. But when the concentration of EGCG was increased to 1.5, 3.75 , and $7.5 \mu \mathrm{M}$, the amount of hydroxyl radicals decreased by $61.1 \%, 83.9 \%$, and $87.9 \%$ respectively [38].

Efficiency in neutralizing hydroxyl radicals by various green tea catechins follows this order: $\mathrm{ECG}>\mathrm{EC}>\mathrm{EGCG}>\mathrm{EGC}$.

Superoxide radical was shown to be neutralized by green tea catechins, vitamin E, rosemary extract, curcumin, and vitamin C. In contact with these, superoxide radical in solution decreased by $72 \pm 7.4 \%, 23 \pm 6.1 \%$ and $23 \pm 5.1 \%, \quad 17 \pm 5.5 \%$ respectively. Green tea catechins in this case were shown to be stronger than vitamin E, rosemary, curcumin, and also vitamin $\mathrm{C}$.

The difference in capturing superoxide radicals by catechins and their epimers was specifically investigated.

Neutralization activity increased in the following order: $\mathrm{EC}<(+) \mathrm{C}<\mathrm{EGC}<\mathrm{GC}<$ EGCG $<$ GCG.
The difference in the activity of EGCG, EGC, EG and their respective epimers, GCG, $\mathrm{GC},(+) \mathrm{C}$, at low concentrations was further studied. The lower the concentration, the greater the difference in their capturing activity [36].

The neutralization activity of catechins relative to lipid free radicals was in the following sequence: $\mathrm{EGCG}>\mathrm{ECG}>\mathrm{EGC}>\mathrm{EC}$.

Free radicals generated by $\mathrm{AAPH}$, were captured as follows, in ascending order of catechin activity: ECG $<(+) \mathrm{C}<\mathrm{EGC}<\mathrm{GC}<$ EGCG < GCG.

The neutralization activity relative to free radicals generated by DPPH (1,1-biphenyl-2picrylhydrazyl), at concentrations of 12.5-25 $\mu \mathrm{m}$, was in the following sequence: $\mathrm{EC}<(+) \mathrm{C}<\mathrm{EGC}$ $<$ GC $<$ EGCG < GCG [38].

Methyl free radicals were trapped by green tea catechins at a much higher rate than by vitamin C.

GCG captured more singlet oxygen (excitedstate oxygen molecules, not a free radical) compared to EGCG.

Therefore, the existing data provides direct evidence that tea catechins capture reactive oxygen compounds (including free radicals).

The range of beneficial health effects from tea is exceptionally broad.

Table 1 shows only some of the biological and health-improving properties of tea extracts.

Table 1. Biological and health-improving properties of tea

\begin{tabular}{l|ll}
\hline No. & Biological Properties of & References \\
\hline Tea & \\
\hline 2. & Antioxidant action & {$[7,12]$} \\
3. & Antisclerotic action & {$[16,20,22]$} \\
& Anticarcinogenic action & {$[14,15,25,27,29-$} \\
4. & & $35]$ \\
5. & Antimutagenic action & {$[26]$} \\
6. & Anti-allergic action & {$[35]$} \\
7. & Antibacterial action & {$[39,40]$} \\
8. & Antimicrobial action & {$[41,42]$} \\
9. & Antivinflammatory action & {$[35]$} \\
10. & Antidiabetic action & {$[43]$} \\
\hline
\end{tabular}

Table 2 shows a partial list, far from complete, of diseases upon which consumption of tea has a beneficial effect. 
Table 2. Beneficial effect of tea consumption on some human diseases

\begin{tabular}{l|ll}
\hline No. & Diseases & References \\
\hline 1 & Different types of cancer & {$[14,15,25,27,29-$} \\
& & $34,37]$ \\
2 & Cardiovascular diseases & {$[16,19,22]$} \\
3 & Stroke & {$[27]$} \\
4 & Diabetes & {$[27,35,36]$} \\
5 & Parkinson's Disease & {$[49,50]$} \\
6 & Alzheimer's disease & {$[27,50]$} \\
7 & Microbial and viral diseases & \\
& -dental caries & {$[51]$} \\
& - HIV & {$[52]$} \\
8 & Aging & {$[53]$} \\
9 & Obesity & {$[54-56]$} \\
\hline
\end{tabular}

\section{Tea and Cardiovascular Diseases}

Cardiovascular disease (CVD) is the main cause of mortality in many countries. CVD accounts for $40 \%$ of all deaths, and mortality from CVD is growing worldwide [57]. In the United States, about 70 million people suffer from CVD.

The useful effects of green tea on CVD have been repeatedly well tested [58-61]; extensive data are provided in numerous reviews [59-63]. Epidemiological studies show a positive causality between tea consumption and reduced risk of CVD [5,64-83].

There are many known causes of CVDs [16]. These include: oxidative stress, impaired lipid metabolism, impaired cardiovascular tone, platelet aggregation, inflammatory processes, growth of cardiovascular cells, etc.

It has been experimentally proven that catechins contribute to the improvement of processes associated with cardiovascular dysfunctions, particularly those related to lipoprotein oxidation, blood aggregation, changes in lipid profile, inflammatory disorders, etc.

In an 11-year study (1995-2005) conducted among 40,000 middle-aged Japanese individuals, it was found that the risk of mortality is $22-33 \%$ lower for those who drank more than two cups of green tea a day, than for those who drank only half a cup [5].
Consumption of about 120-600 $\mathrm{ml}$ of green tea a day for one year reduces the risk of developing hypertension by $46 \%$. In those who consumed more than $600 \mathrm{ml}$ of green tea, the risk of developing hypertension was reduced by $65 \%$ compared with those who drank only $120 \mathrm{ml}$ [70].

Some attempts were also made to establish the relationship between tea consumption and risk of death from cardiovascular diseases $[13,16]$. Among men aged from 65 to 84, annual mortality among those who consumed $0-250 \mathrm{ml}$ of tea a day was 17 per 1,000 people, and among those who consumed $250-500 \mathrm{ml}$ a day, this rate dropped to 8 per 1,000 .

Studies conducted in Holland (Zutphen Elderly Study) demonstrated that among elderly individuals who regularly drank black tea for 5 years, the mortality was by 50 percent lower than among those who did not consume black tea $[71,72]$. According to a multicenter study (Onset Study), mortality from myocardial infarction is lower among people who regularly drink tea than among non-drinkers.

Epidemiological studies in the U. S. have also shown an inverse correlation between tea consumption and risk of CVD [57]. The same relationship was established during the Rotterdam Study in Holland among 3454 adults over 35 years of age [76].

In Japan, the impact of tea consumption on mortality from CVDs was studied on 8552 volunteers. It turned out that daily consumption of 10 cups of tea decreased mortality from CVDs for men by $40 \%$. The striking result was that the same effect was not observed in women [77].

In Norway, a large study was conducted on healthy volunteers (no CVDs or diabetes) with the participation of 9,856 men and 10,223 women. Those that consumed black tea had reduced total cholesterol $[21,75]$.

The first blind placebo-controlled clinical trials of catechins were conducted among patients with moderate hypercholesterolemia in 2003. Total cholesterol decreased by $11 \%$, and lowdensity lipoproteins by $16 \%$ [40]. Intake of catechins in $224 \mathrm{mg}$ and $674 \mathrm{mg}$ doses resulted in 
lower triglyceride levels by $15 \%$ and $29 \%$ respectively.

Other studies show that long-term consumption of green or black tea reduces the risk of cardiovascular diseases, as well as the risk of death related to coronary atherosclerosis. So far, no relationship was identified between the quantity of tea consumption and atherosclerosis, according to a few small epidemiological studies carried out in Australia, Scotland and Wales [81], this may be due to inadequate experiment design - tea type and catechin content were not specified. Different tea varieties are known to have various catechin contents. This is well illustrated in some publications. In addition, the experimental subjects may have included those who smoked, drank alcohol, consumed fatty foods, or had other diseases. There may have been some other factors which affected the results of the experiment. This clearly shows that in such epidemiological studies the content of tea catechins should be accurately specified, tea consumption should be standardized, and subjects should be carefully selected. An excellent review was prepared by L.N.Maslov on the prospects of utilizing the flavonoids in tea and red wine for prevention of atherosclerosis and atherothrombosis [11]

L.N.Maslov suggested that tea catechins "prevent coronary thrombosis rather than atherosclerosis." This is confirmed by many publications in which consumption of green tea was shown to inhibit platelet aggregation. This finding is supported by numerous studies on animals (mice, rats, hamsters, rabbits, monkeys, etc.).

Free-radical oxidation, particularly of lowdensity lipoproteins, is one of the causes of CVD. Oxidized LDL begins to be deposited more rapidly on blood vessel walls, which leads to the development of atherosclerosis. In dozens of studies, green tea catechins have been shown to reduce LDL oxidation.

In the last 10-15 years, many epidemiological studies have been conducted to determine the relationship between tea consumption and incidence of cardiovascular disease.

Japanese researchers established a direct link between consumption of green tea EGCG and the level of coronary artery stenosis. When consumption of green tea was increased from one to four cups a day, the level of stenosis decreased by $65 \%$ [64].

With increased consumption of flavonoids, mortality from cardiovascular diseases in different countries decreased by $65 \%$ (Finland > USA > Greece > Italy > Netherlands > Japan) (V.A. Tutelyan, private lectures).

It is commonly believed that green tea prevents cardiovascular diseases better than black tea. This is based on the low level of cardiovascular disease and cancer in Asian countries where primarily green tea is consumed. However, in recent years, research conducted on hamsters has shown that the effect of green and black teas is equivalent. Both types of tea effectively inhibited atherosclerosis. Atherosclerosis is inhibited by three mechanisms: hypolipemic, antioxidant, and antifibrinolytic. In animal studies, it was shown that tea consumption reduces plasma content of LDL, the LDL/HDL ratio, triglycerides content, lipid peroxides, and fibrinogen.

Studies in Korea have shown that tea consumption lowers LDL ratio and the LDL/HDL ratio.

In a large Chinese study, it was found that consumption of one capsule of concentrated tea extract (equivalent to 7 cups of black tea per day) reduced LDL by $16 \%$ in patients with high cholesterol on a low-fat diet.

Among American subjects with moderate cholesterol, the intake of 5 cups of black tea reduced cholesterol and LDL. Epidemiological studies in the United States have shown that consumption of 2 or more cups of tea a day can reduce by half the number of deaths from heart attacks.

\section{Tea and Cancer}

Cancer is the second cause of deaths both in the United States and in Russia - each year five hundred thousand people die from cancer. Conventional treatment of oncological diseases includes surgery and chemotherapy. Many studies have shown that consumption of natural 
antioxidants can reduce the risk of cancer. Green tea is especially effective in this regard.

General issues related to oncological diseases and tea are discussed in numerous publications [14,25,34,84-122].

Research on cancer cell lines in animals and humans has shown that catechins and other tea constituents inhibit or block the development of cancer. Some types of cancer, for which beneficial effects via green tea and its components may be facilitated, are provided in Table 3.

Table 3. Types of Cancer; Beneficial Effects Facilitated by Green Tea and Its Components

\begin{tabular}{l|ll}
\hline No. & Types of Cancer & \multicolumn{1}{c}{ References } \\
\hline 1. & Breast cancer in & {$[103,122-125]$} \\
& women & \\
2. & Lung cancer & {$[109,114,126-129]$} \\
3. & Stomach cancer & {$[99,102,118,122,130-$} \\
& & $132]$ \\
4. & Prostate cancer in & {$[108,110,113,133-$} \\
& men & $135]$ \\
5. & Rectal cancer & {$[136,137]$} \\
6. & Colon cancer & {$[101,107,119,120,138]$} \\
7. & Esophageal cancer & {$[131,139]$} \\
8. & Skin cancer & {$[140]$} \\
9. & Kidney cancer & {$[141]$} \\
10. & Bladder cancer & {$[141]$} \\
11. & Pancreatic cancer & {$[35,115,117]$} \\
12. & Oral cancer & {$[111]$} \\
13. & Adenocarcinoma & {$[112]$} \\
14. & Leukemia & {$[121]$} \\
\hline
\end{tabular}

Green Tea for Cancer Prevention. One of the anti-carcinogenic mechanisms of action of green tea catechins was identified. EGCG increases synthesis of glutathione-S-transferase enzymes which neutralize various toxins, some of which cause cancer through DNA damage. People in China and Japan who regularly consume large amounts of green tea, are less prone to cancer than people in other countries where green tea is consumed in smaller quantities or not consumed at all.

Studies conducted on people with low enzyme activity showed that the use of green tea concentrates (Polyphenon E) by $800 \mathrm{mg}$ (4 capsules) in the morning for four weeks, increased the activity of enzymes of the glutathione-S-transferase family by $80 \%$. Polyphenon does not affect people with initially high or moderate activity level of these enzymes. Therefore, according to the author of this publication (S. Chow, Arizona Cancer Center), green tea extract can be used to prevent cancer in people with low activity of glutathione-Stransferase enzymes.

Chemoprevention of prostate cancer using green tea catechins. The incidence of prostate cancer is growing both in European countries and the United States. Currently, of all cancer-related deaths, prostate cancer is the second highest cause of death among men.

Clinical trials were carried out to assess the efficacy and safety of green tea catechins to prevent prostate cancer in patients with highgrade prostatic intraepithelial neoplasia (PIN) [110].

The green tea preparation consisted of a catechin mixture isolated by HPLC: EGC $-5.5 \%$, $\mathrm{EC}-12.24 \%$, EGCG - 51.88\%, ECG - 6.12\% (total catechins 75.7\%). This preparation contained less than $1 \%$ of caffeine. The daily dose was $600 \mathrm{mg}$ - three $200 \mathrm{mg}$ capsules.

In the group of 30 patients receiving the capsules for one year, only one tumor was diagnosed (the probability of disease is $3 \%$ ). In the group of similar patients receiving placebo, nine cancer tumors were detected (probability is $30 \%)$.

The values of PSA (prostate-specific antigen) were lower in patients treated with catechins.

No side effects were detected in patients taking catechins.

Only positive effects were noted, such as reduction of lower urinary tract symptoms.

Low incidence of cancer in Asian countries compared to the Western countries is associated with regular consumption of green tea [133].

Interestingly, the Asian immigrants in the USA who do not drink green tea are at the same risk of developing cancer as the national average level.

Antitumor effect of tea catechins, especially of epigallocatechin gallate, has been shown in experiments on animals in vitro and in vivo $[134,135]$. 
The efficacy of treatment can be as high as $90 \%$ in men at risk when green tea catechins are administered orally [110]. These same studies also showed that green tea catechins are safe for humans.

Impact of green tea catechins on leukemia. EGCG consumption shows a positive impact on leukemia at an early stage. Lymphocyte content is reduced in $30 \%$ of patients. Patients with chronic lymphocytic leukemia are tolerant to high doses of EGCG. 33 patients received different amounts of Polyphenon E (60\% EGCG) ranging from $200 \mathrm{mg}$ to $2,000 \mathrm{mg}$ twice a day. The maximum allowable norm was not reached. This type of leukemia is the most common type in the USA; $50 \%$ of patients have an aggressive form of the disease and die early.

Remission of chronic lymphocytic leukemia was observed at high doses of EGCG. Researchers hope that EGCG may stabilize the disease at an early stage and enhance the effectiveness of treatment in combination with other therapies [121].

\section{Other Health-Beneficial Properties of Tea}

Green tea improves bone condition. According to Zhonglan Bin from Hong Kong University (published in J. Agric. Food Chem.), green tea may improve bone condition-it stimulates the growth of bone tissue and prevents osteoporosis. The most active catechins for this purpose is epigallocatechin (EGC) - it increases the activity of key enzymes, promotes bone growth by $79 \%$ while also increasing the level of mineralization of bone tissue. High concentrations of EGC block the activity of osteoclasts-cells that destroy bone tissue. Green tea catechins do not have a toxic effect on cells. Experiments were conducted on the cells of rats.

Tea helps with stress. M. Cross, psychologist from the University of London, has shown that tea has a calming effect in stressful situations [142-145].

According to surveys, $70 \%$ of the British drink tea before making critical decisions.

Tea lowers blood pressure. Studies conducted by the University of Florida, Harvard Medical School and Food Research Institute in Boston have shown that extracts of green tea administered for three weeks reduced systolic/diastolic blood pressure and reduced LDL levels down to $9 \mathrm{mg} / \mathrm{dL}$. At the same time, the concentration of malondialdehyde, a marker of oxidative stress, was reduced. During oxidative stress, the levels of free radicals in the body exceed the norm, which can lead to dangerous diseases and premature aging.

Epigallocatechin gallate (EGCG) in green tea increases the shelf life of platelets. When stored, the platelets undergo biochemical changes which make their cell membranes lose their functional characteristics and hemostatic properties. When EGCG is added to platelets, their active functions are preserved for longer periods (1.5-2 times). Chinese University Professor S-K. Chion who conducted relevant studies suggested that EGCG prevents activation of platelet cells and protects their membrane lipids from oxidation. These findings open up new possibilities for storing platelets.

HIV prevention with green tea. Dr. Williamson, M. P. from the University of Sheffield, England, demonstrated that epigallocatechin gallate (EGCG) from green tea enters into the human immune system faster than the immunodeficiency virus [145a]. Thus, the spread of HIV in the body is slowed down. However, the author believes that EGCG cannot protect against the infection, but, in combination with conventional therapy, may improve the quality of life of HIV-infected patients. Studies on the role of EGCG continue

Green tea is effective against sepsis. Sepsis (blood poisoning) is an infectious disease that develops when various microorganisms that produce toxins enter in human blood in conditions of reduced body resistance. In the Russian Federation, sepsis is the third cause of deaths of women in childbirth and of newborn babies. Scientists from the Michigan University showed that consumption of EGCG increased the survival of mice with sepsis by three times.

Consumption of EGCG is also effective for rheumatoid arthritis, an autoimmune disease.

Consumption of green tea improves cognitive abilities and memory [146]. 
GABA and Gabaron teas contain elevated levels of gamma-aminobutyric acid $(\gamma-$ aminobutyric acid, GABA). Gammaaminobutyric acid (GABA) is a universal inhibitory neurotransmitter which reduces the overall activity of the brain, especially during sleep. GABA was first found in the brain by Roberts at al. in 1950.

GABA tea was first developed in 1987 in Japan [146]. GABA content in this tea was $150 \mathrm{mg}$ per $100 \mathrm{~g}$. The amount of GABA in plant tissues typically ranges from 0.3 to $32 \mu \mathrm{mol} / \mathrm{g}$.

When tea leaves (oolong tea, black tea) undergo anaerobic treatment for more than 10 hours, the content of GABA and alanine rises 8 and 5 times, respectively, while the content of glutamic and aspartic acid is reduced by $80-90 \%$. Specialized GABA tea is considered to have a therapeutic effect as it shows many beneficial biological actions.

The primary biological functions of GABA tea include: it produces a reduction in blood pressure in humans [147]; it plays an important role in cardiovascular regulation [148]; counteracts low GABA levels in plasma which may affect Parkinson's disease, epilepsy [149,150], alcoholism [151,152], depression [149,150], and menopause [149,150]; it helps cure stress-related insomnia as well as insomnia in elderly people, and improves sleep quality [149,150,153]; helps cure alcoholism-alcoholics have decreased GABA content in the blood [154,155]; alleviates depression (WHO estimates that by 2020 depression will be the second most common disease after cardiovascular diseases [154]; GABA helps in the treatment of diabetes [155], Alzheimer's disease [149,150], and prevents premature aging [155]. ${ }^{176}$

Clinical trials have been conducted to assess the effect of GABA tea [156] and compare the biological activity of GABA tea and green tea. ${ }^{178}$

GABA is produced in inert carbon dioxide more effectively then in nitrogen, yet nitrogen is recommended due to its cost-effectiveness and safety. Anaerobic treatment of tea does not alter the content of tannins, caffeine, and theanine.

\section{Conclusion}

This brief review clearly demonstrates that tea-especially green tea-is beneficial to human health. In addition, several publications in recent years also show consumption of black tea to be as beneficial as that of green tea. Some companies have begun to sell mechanical mixtures of green and black tea. Special attention should be paid to the oolong or wulong tea (fermented by 50\%), which are the most popular tea varieties in China and Taiwan $(80 \%$ of the population consume wulong tea). Some scientists suggested that these teas may have even greater potential for improving human health. Unfortunately, they are not sufficiently studied yet. The effects of Pu-erh tea on health also need extensive research.

For the sake of fair-mindedness, it should be noted that despite the thousands of articles on the benefits of tea, there are a few publications on the harm of tea consumption. For example, one publication presents some cases of hepatotoxicity related to consumption of green tea [157]. Yet, another publication demonstrates on a large number of volunteers that green tea does not alter liver functions in any way [158]. The most recent publications have examined the biochemical and pharmaceutical properties of tea catechins and their impact on human health [159-164]. We would like to conclude this review with an appeal, 'Drink tea for the benefits to your health!'

\section{Acknowledgments}

The authors would like to thank Jing Yuan Wang for her excellent technical assistance.

\section{References}

1. Weinreb, O.; Amit, T.; Youdim, M.B.H.; Mandel, S., Chapter 15. Green tea flavan-3ols and their role in protecting against Alzheimer's and Parkinson's disease pathophysiology. In book: Flavonoids and Related Compounds. CRC Press 2012. DOI: 10.1201/b11872-16

2. Handbook of green tea and health research. Nova Science 2009. 
3. Crozier, A.; Ashihara, H.; Tomás-Barberan, F., Teas, cocoa and coffee: Plant secondary metabolites and health Wiley-Blackwell, 2011.

4. Barbosa, D.S., Green tea polyphenolic compounds and human health. J. Verbr. Lebensm 2007, 2, 407-413.

DOI: $10.1007 / \mathrm{s} 00003-007-0246-\mathrm{Z}$

5. Kuriyama, S.; Shimazu, T.; Ohmori, K.; Kikuchi, N.; Nakaya, N.; Nishino, Y.; Tsubono, Y.; Tsuji, I., Green tea consumption and mortality due to cardiovascular disease, cancer, and all causes in Japanthe Ohsaki study. JAMA 2006, 296, 1255-1265. DOI: 10.1001/jama.296.10.1255.

6. Khan, N.; Mukhtar, H., Tea polyphenols for health promotion. Life Sci. 2007, 81, 519533. DOI: $10.1016 /$ j.lfs.2007.06.011

7. Higdon, J.; Frei, B., Tea catechins and polyphenols health effects, metabolism, and antioxidant functions. Crit Rev Food Sci Nutr. 2003, 43, 89-143. DOI: $\underline{10.1080 / 10408690390826464}$

8. Sato, T.; Miyata, G., The nutraceutical benefit, part i: Green tea. Nutrition 2007, 16, 315-317.

9. Dufresne, C.J.; Farnworth, E.R., A review of latest research findings on the health promotion properties of tea. J Nutr Biochem. 2001, 12, 404-421. DOI: 10.1016/S09552863(01)00155-3

10. Sang, S.; Hou, Z.; Lambert, J.D.; Yang, C.S., Redox properties of tea polyphenols and related biological activities. Antioxid Redox Signal 2005, 7, 1704-1714. DOI: 10.1089/ars.2005.7.1704

11. Feng, W.Y., Metabolism of green tea catechins: An overview. Curr Drug Metab 2006, 7, 755-809. DOI: $10.2174 / 138920006778520552$

12. Rietveld, A.; Wiseman, S., Antioxidant effects of tea evidence from human clinical trials. American Society for Nutritional Sciences. 2003, 22, 3285S-3292S.

13. Wheeler, D.S.; Wheeler, W.J., The medicinal chemistry of tea. Drug Development Research 2004, 61, 45-65. DOI: $10.1002 / \mathrm{ddr} .10341$.
14. Yang, C.S.; Sang, S.; Lambert, J.D.; Hou, Z.; Ju, J.; Lu, G., Possible mechanisms of the cancer-preventive activities of green tea. Molecular nutrition \& food research 2006, 50, 170-175. DOI: $10.1002 / \mathrm{mnfr} .200500105$

15. Chen, D.; Dou, Q.P., Tea polyphenols and their roles in cancer prevention and chemotherapy. International journal of molecular sciences 2008, 9, 1196-1206.

DOI: 10.3390/ijms9071196

16. Velayutham, P.; Babu, A.; Liu, D., Green tea catechins and cardiovascular health an update. Curr Med Chem. 2008, 15, 18401850.

17. Diane L. McKay, P., and Jeffrey B. Blumberg, PhD, FACN, The role of tea in human health an update. Journal of the American College of Nutrition 2002, 21, 113.

18. Hara, Y., Green tea: Health benefits and applications. CRC Press: 2001; p 240.

19. Tijburg, L.B.M.; Mattern, T.; Folts, J.D.; Weisgerber, U.M.; Katan, M.B., Tea flavonoids and cardiovascular diseases a review. Critical reviews in food science and nutrition 1997, 37, 771-785. DOI: 10.1080/10408399709527802

20. Crespy, V.; Williamson, G., A review of the health effects of green tea catechins in in vivo animal models. American Society for Nutritional Sciences 2004, 22, 3431S-3440S.

21. Luczaj, W.; Welerowicz, T.; Skrzydlewska, E.; Buszewski, B., Chromatographic examinations of tea's protection against lipid oxidative modifications. Toxicology mechanisms and methods 2008, 18, 483-490. DOI: 10.1080/15376510701624050.

22. Maslov, L.N., On the prospects of flavonoids use for prevention of atherosclerosis and atherothrombosis. Clinical Pharmacology and Therapy 2007, 16, 60-67.

23. Rawel, H.M.; Kulling, S.E., Nutritional contribution of coffee, cacao and tea phenolics to human health. Journal für Verbraucherschutz und Lebensmittelsicherheit 2007, 2, 399-406. DOI: $10.1007 / \mathrm{s} 00003-007-0247-y$ 
24. Baraboi, V.A., Catechins of tea plants: Structure, activity, and use. Biotechnology 2008, 1, 23-36.

25. Yang, C.S.; Wang, Z.-Y., Tea and cancer. $J$ Natl Cancer Inst. 1993, 85, 1038-1049 DOI: 10.1093/jnci/85.13.1038.

26. Gupta, S.; Saha, B.; Giri, A.K., Comparative antimutagenic and anticlastogenic effects of green tea and black tea a review. Mutation Research 2002, 512, 37-65. DOI: 10.1016/S1383-5742(02)00024-8.

27. Zaveri, N.T., Green tea and its polyphenolic catechins: Medicinal uses in cancer and noncancer applications. Life sciences 2006, 78, 2073-2080. DOI: 10.1016/j.lfs.2005.12.006.

28. Yamamoto, T.; Juneja, L.R.; Chu, s.-C.; Kim, M., Chemistry and applications of green tea CRC Press: 1997; p 176.

29. Chung, F.-L.; Schwartz, J.; Herzog, C.R.; Yang, Y.-M., Tea and cancer prevention studies in animals and humans. J Nutr. 2003, 10, 3268S-3274S.

30. Kim, M.S.; Masuota, M., Cancer chemoprevention by green tea polyphenols. CRC Press 1997.

31. Imai, K.; Suga, K.; Nakach, K., Cancerpreventive effects of drinking green tea among a Japanese population. Preventive Medicine 1997, 26, 769-775. DOI: 10.1006/pmed.1997.0242.

32. Kohlmeier, L.; Weterings, K.G.C.; Steck, S.; Kok, F.J., Tea and cancer prevention an evaluation of the epidemiologic literature. Nutrition and Cancer 1997, 27, 1-13. DOI: $\underline{10.1080 / 01635589709514494}$

33. Landau, J.M.; D, L.J.; Lee, M.J.; S, Y.C., Cancer prevention by tea and tea constituents. CRC Taylor and Francis: New York, 2005.

34. Yang, C.S.; Maliakal, P.; Meng, X., Inhibition of carcinogenesis by tea. Annu. Rev. Pharmacol. Toxicol 2002, 42, 25-54. DOI:10.1146/annurev.pharmtox.42.082101.1 $\underline{54309}$

35. Ho, C.T.; Lin, J.K.; Shahidi, F., Tea abd tea products. CRC Press: London, 2009.

36. Cabrera, C.; Artacho, R.; Gimenez, R., Beneficial effects of green tea-a review.
Journal of the American College of Nutrition 2006, 25, 79-99. DOI: 10.1080/07315724.2006.10719518

37. Fujiki, H., Green tea: Health benefits as cancer preventive for humans. Chemical record 2005, 5, 119-132. DOI: 10.1002/tcr.20039

38. Zhao, B.; Guo, Q.; Xin, W., Free radical scavenging by green tea polyphenols Methods in Enzymology 2001, 355, 217-231. DOI: 10.1016/S0076-6879(01)35245-X

39. Sharquie, K.E.; al-Turfi, I.A.; al-Salloum, S.M., Antibacterial activity of tea in vivo and in vitro in patients with impetigo contagiosa. J. Dermatology 2000, 27, 706710.

40. Yamamoto, Y.; Matsunaga, K.; Friedman, H., Protective effects of green tea catechins on alveolar macrophages against bacterial infections. Biofactors 2004, 21, 119-121.

41. Kubo, I.; Muroi, H.; Himejima, M., Antimicrobial activity of green tea flavor components and their combination effects. $J$. Agrlc. Food Chem. 1992, 1902, 245-240. DOI: $10.1021 / \mathrm{jf00014a015}$

42. Taylor, P.W.; Hamilton-Miller, J.M.T.; Stapleton, P.D., Antimicrobial properties of green tea catechins. Food Sci Technol Bull. 2005, 2, 71-81.

43. Gianfrancoa, F.; Buffa, A.; Benelli, R.; Varnier, O.; Noonan, D.; Albini, A., Polyphenolic antioxidant (-)epigallocatechin-3-gallate from green tea as a candidate anti-hiv agent. AIDS 2002, 16, 939-941.

44. Polychronopoulos, E.; Zeimbekis, A.; Kastorini, C.M.; Papairakleous, N.; Vlachou, I.; Bountziouka, V.; Panagiotakos, D.B., Effects of black and green tea consumption on blood glucose levels in non-obese elderly men and women from mediterranean islands (medis epidemiological study). European journal of nutrition 2008, 47, 10-16. DOI: 10.1007/s00394-007-0690-7.

45. Iso, H.; Date, C.; Wakai, K.; Fukui, M.; Tamakoshi, A., The relationship between green tea and total caffeine intake and risk for self-reported type 2 diabetes among 
Japanese adults. Ann Intern Med. 2006, 144, 554-562.

46. Fukino, Y.; Ikeda, A.; Maruyama, K.; Aoki, N.; Okubo, T.; Iso, H., Randomized controlled trial for an effect of green teaextract powder supplementation on glucose abnormalities. European journal of clinical nutrition 2008, 62, 953-960. DOI: 10.1038/sj.ejcn.1602806.

47. Mackenzie, T.; Leary, L.; Brooks, W.B., The effect of an extract of green and black tea on glucose control in adults with type 2 diabetes mellitus: Double-blind randomized study. Metabolism: clinical and experimental 2007, 56, 1340-1344. DOI: 10.1016/j.metabol.2007.05.018

48. Vinson, J.A.; Teufel, K.; Wu, N., Green and black teas inhibit atherosclerosis by lipid, antioxidant, and fibrinolytic mechanisms. $J$. Agric. Food Chem. 2004, 52, 3661-3665. DOI: $10.1021 / \mathrm{jf0352551}$

49. Pan, T.; Jankovic, J.; Le, W., Potential therapeutic properties of green tea polyphenols in Parkinson's disease. Drugs Aging 2003, 20, 711-721. DOI: 10.2165/00002512-200320100-00001

50. Lee, H.; Bae, J.H.; Lee, S.R., Protective effect of green tea polyphenol egcg against neuronal damage and brain edema after unilateral cerebral ischemia in gerbils. $J$ Neurosci Res. 2004, 77, 892-900. DOI: 10.1002/jnr.20193

51. Ferrazzano, G.F.; Amato, I.; Ingenito, A.; De Natale, A.; Pollio, A., Anti-cariogenic effects of polyphenols from plant stimulant beverages (cocoa, coffee, tea). Fitoterapia 2009, $80, \quad 255-262$. DOI: 10.1016/j.fitote.2009.04.006

52. Nance, C.L.; Shearer, W.T., Is green tea good for hiv-1 infection. J Allergy Clin Immunol 2003, 112, 851-853. DOI: 10.1016/j.jaci.2003.08.048

53. Junqueira, V.B.; Barros, S.B.; Chan, S.S.; Rodrigues, L.; Giavarotti, L.; Abud, R.L.; Deucher, G.P., Aging and oxidative stress. Molecular aspects of medicine 2004, 25, 516.

54. Kao, Y.-h.; Hiipakka, R.A.; Liao, S., Modulation of obesity by a green tea catechin. Am J Clin Nutr 2000, 72, 12321241.

55. Kajimoto, O.; Kotani, K.; Kajimoto, Y.; Suzuki, Y.; Sagesaka, Y.M.; Yabune, M.; Nozawa, A.; Kakuda, T.; Nagata, K.; Nakamura, T., et al., Tea catechins with a galloyl moiety reduce body weight and fat. Journal of Health Science 2005, 51, 161171. DOI: $10.1248 /$ jhs.51.161

56. Diepvens, K.; Kovacs, E.M.; Vogels, N.; Westerterp-Plantenga, M.S., Metabolic effects of green tea and of phases of weight loss. Physiology \& behavior 2006, 87, 185191. DOI: 10.1016/j.physbeh.2005.09.013

57. Preventing heart disease and stroke: Addressubg the nation's leading killers; Centers for Disease Control and Prevention Washington, DC: 2005.

58. Shenouda, S.M.; Vita, J.A., Effects of flavonoid-containing beverages and egcg on endothelial function. Journal of the American College of Nutrition 2007, 26, 366S-372S.

59. Stangl, V.; Dreger, H.; Stangl, K.; Lorenz, M., Molecular targets of tea polyphenols in the cardiovascular system. Cardiovascular research 2007, 73, 348-358. DOI: 10.1016/j.cardiores.2006.08.022

60. Stangl, V.; Lorenz, M.; Stangl, K., The role of tea and tea flavonoids in cardiovascular health. Molecular nutrition \& food research 2006, 50, 218-228. DOI: 10.1002/mnfr.200500118

61. Vita, J.A., Tea consumption and cardiovascular disease effects on endothelial function. J Nutr. 2003, 133, 3293S-3297S.

62. Dhalla, N.; Temsah, R.; Netticadan, T., Role of oxidative stress in cardiovascular diseases. J Hypertens. 2000, 18, 655-673. DOI: $10.1161 /$ CIRCULATIONAHA.107.728394

63. Jain, K.S.; Kathiravan, M.K.; Somani, R.S.; Shishoo, C.J., The biology and chemistry of hyperlipidemia. Bioorg Med Chem. 2007, 15, 4674-4699. DOI: 10.1016/j.bmc.2007.04.031

64. Sasazuki, S.; Kodama, H.; Yoshimasu, K.; Liu, Y.; Washio, M.; Tanaka, K.; Tokunaga, S.; Kono, S.; Arai, H.; Doi, Y., et al., Relation between green tea consumption and 
the severity of coronary atherosclerosis among japanese men and women. AEP 2000, 10, 401-408.

65. Imai, K.; Nakachi, K., Cross sectional study of effects of drinking green tea on cardiovascular and liver diseases. BMJ 1995, 310, 693-696. DOI: 10.1136/bmj.310.6981.693

66. Vita, J.A., Endothelial function: A barometer for cardiovascular risk? Circulation 2002, 106, 640-642. DOI: $10.1161 /$ 01.CIR.0000028581.07992.56

67. Ruggeri, Z.M., Platelets in atherothrombosis. Nature Medicine 2002, 8, 1227-1234. DOI: $10.1038 / \mathrm{nm} 1102-1227$

68. Zouridakis, E.; Avanzas, P.; ArroyoEspliguero, R.; Fredericks, S.; Kaski, J.C., Markers of inflammation and rapid coronary artery disease progression in patients with stable angina pectoris. Circulation 2004, 110, 1747-1753. $\quad$ DOI: $10.1161 /$ 01.CIR.0000142664.18739.92

69. Chacko, S.; Nhambi, P.; Kuttan, R.; Nishigaki, I. Beneficial effects of green tea: A Literature review. Chinese Medicine. 2010, 5, 13-22. DOI: 1 0.1186/1749-8546-513

70. Yang, Y.-C.; Lu, F.-H.; Wu, J.-S.; Wu, C.H.; Chang, C.-J., The protective effect of habitual tea consumption on hypertension. Arch Intern Med 2004, 164, 1534-1540. DOI: 10.1001/archinte.164.14.1534.

71. Hertog, M.G.; Feskens, E.J.; Hollman, P.C.; Katan, M.B.; Kromhout, D., Dietary antioxidant flavonoids and risk of coronary heart disease: The Zutphen elderly study. Lancet. 1993, 342, 1007-1011. DOI: 10.1016/0140-6736(93)92876-U

72. Hertog, M.G.; Feskens, E.J.; Kromhout, D., Antioxidant flavonoids and fisk of coronary heart disease Lancet 1997, 349, 699.

73. Mukamal, K.J., Tea consumption and mortality after acute myocardial infarction. Circulation 2002, 105, 2476-2481. DOI: 10.1161/01.CIR.0000017201.88994.F7.

74. Sesso, H.D.; Gaziano, J.M.; Buring, J.E.; Hennekens, C.H., Coffee and tea intake and the risk of myocardial infarction. American
Journal of Epidemiology 1999, 149, 162167.

75. Stensvold, I.; Tverdal, A.; Solvoll, K.; Foss, O.P., Tea consumption. Relationship to cholesterol, blood pressure, and coronary and total mortality. Prev Med. 1992, 24, 546553. DOI: 10.1016/0091-7435(92)90062-M

76. Geleijnse JM; Launer LJ; Hofman A; Pols HA; JC., W., Tea flavonoids may protect against atherosclerosis: The rotterdam study. Arch Intern Med. 1999, 18, 2170-2174. DOI: 10.1001/archinte.159.18.2170

77. Nakachi, K.; Matsuyama, S.; Miyake, S.; Suganuma, M.; Imai, K., Preventive effects of drinking green tea on cancer and cardiovascular disease: Epidemiological evidence for multiple targeting prevention. Biofactors 2000, 13, 49-54.

78. Sano, J.; Inami, S.; Seimiya, K.; Ohba, T.; Sakai, S.; Takano, T.; Mizuno, K., Effects of green tea intake on the development of coronary artery disease. Circ $J$ 2004, 68, 665-670. DOI: 10.1253/circj.68.665

79. Hertog, M.G.; Sweetnam, P.M.; Fehilv, A.M.; Elwood, P.C.; Kromhout, D., Antioxidant flavonols and ischemic heart disease in a welsh population of men the caerphilly study. Am J Clin Nutr 1997, 65, 1489-1494.

80. Kuriyama, S., The relation between green tea consumption and cardiovascular disease as evidenced by epidemiological studies. $J$. Nutr. 2008, 138, 1548S-1553S

81. Woodward, M.; Tunstall-Pedoe, H., Coffee and tea consumption in the scottish heart health study follow up conflicting relations with coronary risk factors, coronary disease, and all cause mortality. Journal of Epidemiology and Community Health 1999, 53, 481-487.

82. Maron, D.J.; Lu, G.P.; Cai, N.S.; Wu, Z.G.; Li, Y.H.; Chen, H.; Zhu, J.Q.; Jin, X.J.; Wouters, B.C.; Zhao, J., Cholesterollowering effect of a theaflavin-enriched green tea extract a randomized controlled trial. Arch Intern Med 2003, 163, 1448-1458. DOI: $10.1001 /$ archinte.163.12.1448

83. Unno, T.; Tago, M.; Suzuki, Y.; Nozawa, A.; Sagesaka, Y.M.; Kakuda, T.; Egawa, K.; 
Kondo, K., Effect of tea catechins on postprandial plasma lipid responses in human subjects. British Journal of Nutrition 2007, 93, 543. DOI: 10.1079/BJN20041379

84. Mukhtar, H.; Ahmad, N., Tea polyphenols prevention of cancer and optimizing health. Am J Clin Nutr 2000, 71, 1698S-1702S.

85. Katiyar, S.; Mukhtar, H., Tea in chemoprevention of cancer. Int $J$ Oncol. 1996, 8, 221-238.

86. Conney, A.; Lu, Y.; Lou, Y.; Xie, J.; Huang, M., Inhibitory effect of green and black tea on tumor growth. Proc Soc Exp Biol Med. 1999, 220, 229-233. DOI: 10.3181/00379727-220-44371

87. Shukla, Y.; Taneja, P., Anticarcinogenic effect of black tea on pulmonary tumors in swiss albino mice. Cancer Letters 2002, 176, 137-141.

88. Kuroda, Y.; Hara, Y., Antimutagenic and anticarcinogenic activity of tea polyphenols. Mutat Res. 1999, 436, 69-97. DOI: 10.1016/S1383-5742(98)00019-2

89. Fujiki, H., Two stages of cancer prevention with green tea. J Cancer Res Clin Oncol. 1999, 125, 589-597. DOI: 10.1007/s004320050321.

90. Ahmad, N.; Mukhtar, H., Green tea polyphenols and cancer biologic mechanisms and practical implications. Nutrition Reviews 1999, 57, 78-83. DOI: 10.1111/j.1753-4887.1999.tb06927.x

91. Lin, J.K.; C., L.Y., Cancer prevention by tea polyphenols. Proc. Nutl. Sci. counc rep. China 2000, 24, 1-13.

92. Kazi, A.; Smith, D.M.; Daniel, K.; Zhong, S.; Gupta, P.; Bosley, M.E.; P., D.Q., Potential molecular targets of tea polyphenols in human tumor cells: Significance in cancer prevention. In Vivo. 2002, 16, 397-403.

93. Gupta, S.; Ahmad, N.; Mohan, R.R.; Husain, M.M.; Mukhtar, H., Prostate cancer chemoprevention by green tea in vitro and in vivo inhibition of testosterone-mediated induction of ornithine decarboxylase. Cancer research 1999, 59, 2115-2121.

94. Bushman, J.L., Green tea and cancer in humans: A review of the literature. Nutr
Cancer 1998, 32, 151-159. DOI: 10.1080/01635589809514697

95. Lambert, J., Cancer chemopreventive activity and bioavailability of tea and tea polyphenols.

Mutation

Research/Fundamental and Molecular Mechanisms of Mutagenesis 2003, 523-524, 201-208. $\quad$ DOI: $\quad 10.1016 / \mathrm{S} 0027-$ 5107(02)00336-6

96. Lin, J.K., Cancer chemotherapy by tea polyphenols. Arch. Pharm. res. 2002, 25, 361-371.

97. Y Sadzuka, T.S.a.S.H., Modulation of cancer chemotherapy by green tea. Clin Cancer Res 1998, 4, 153-156.

98. Han, C., Screening of anticarcinogenic ingredients in tea polyphenols. Cancer Letters 1997, 114, 153-158. DOI: 10.1016/S0304-3835(97)04647-8

99. Hibasami, H.; Jin, Z.X.; Hasegawa, M.; Urakawa, K.; Nakagawa, M.; Ishii, Y.; Yoshioka, K., Oolong tea polyphenol extract induces apoptosis in human stomach cancer cells. Anticancer Res. 2000, 20, 4403-4406.

100. Kim, M.; Masuda, M., Cancer prevention by green tea polyphenols. CRC Press Boca Raton, 1997.

101. Suzuki, Y.; Tsubono, Y.; Nakaya, N.; Koizumi, Y.; Suzuki, Y.; Shibuya, D.; Tsuji, I., Green tea and the risk of colorectal cancer: Pooled analysis of two prospective studies in Japan. J Epidemiol. 2005, 15, 118124. DOI: $10.2188 /$ jea. 15.118

102. Sasazuki, S.; Inoue, M.; Hanaoka, T.; Yamamoto, S.; Sobue, T.; Tsugane, S., Green tea consumption and subsequent risk of gastric cancer by subsite: The JPHC study. Cancer Causes Control. 2004, 15, 483-491.

DOI: 10.1023/B:CACO.0000036449.68454.42

103. Zhang, M.; Holman, C.D.; Huang, J.P.; Xie, $X$., Green tea and the prevention of breast cancer: A case-control study in southwest China. Carcinogenesis 2008, 29, 1594-1600. DOI: $10.1093 /$ carcin/bgl252

104. Y, S., Tea and cancer chemoprevention: A comprehensive review. Asian Pac J Cancer Prev. 2007, 8, 155-166. 
105. de Mejia, E.G.; Ramirez-Mares, M.V.; Puangpraphant, S., Bioactive components of tea: Cancer, inflammation and behavior. Brain Behav Immun. 2009, 23, 721-731. DOI: 10.1016/j.bbi.2009.02.013

106. Carlson, J.R.; Bauer, B.A.; Vincent, A.; Limburg, P.J.; Wilson, T., Reading the tea leaves: Anticarcinogenic properties of (-)epigallocatechin-3-gallate.. Mayo Clin Proc. 2007, 82, 725-732. DOI: $10.4065 / 82.6 .725$

107. Kumar, N.; Shibata, D.; Helm, J.; Coppola, D.; Malafa, M., Green tea polyphenols in the prevention of colon cancer. Front Biosci. 2007, 1, 2309-2315.

108. Stuart, E.C.; Scandlyn, M.J.; Rosengren, R.J., Role of epigallocatechin gallate (EGCG) in the treatment of breast and prostate cancer. Life Sci. 2006, 79, 23292336. DOI: 10.1016/j.lfs.2006.07.036

109. Arts, I.C., A review of the epidemiological evidence on tea, flavonoids, and lung cancer. J Nutr. 2008, 138, 1561S-1566S.

110. Bettuzzi, S.; Brausi, M.; Rizzi, F.; Castagnetti, G.; Peracchia, G.; Corti, A., Chemoprevention of human prostate cancer by oral administration of green tea catechins in volunteers with high-grade prostate intraepithelial neoplasia: A preliminary report from a one-year proof-of-principle study. Cancer research 2006, 66, 12341240. DOI: 10.1158/0008-5472.CAN-05$\underline{1145}$

111. Ide, R.; Fujino, Y.; Hoshiyama, Y.; Mizoue, T.; Kubo, T.; Pham, T.M.; Shirane, K.; Tokui, N.; Sakata, K.; Tamakoshi, A., et al., A prospective study of green tea consumption and oral cancer incidence in Japan. Ann Epidemiol. 2007, 17, 821-826. DOI: 10.1016/j.annepidem.2007.04.003

112. Kakuta, Y.; Nakaya, N.; Nagase, S.; Fujita, M.; Koizumi, T.; Okamura, C.; Niikura, H.; Ohmori, K.; Kuriyama, S.; Tase, T., et al., Case-control study of green tea consumption and the risk of endometrial endometrioid adenocarcinoma. Cancer Causes Control. 2009, 20, 617-624. DOI: 10.1007/s 10552$\underline{008-9272-0}$

113. Kurahashi, N.; Sasazuki, S.; Iwasaki, M.; Inoue, M.; Tsugane, S.; Group., J.S., Green tea consumption and prostate cancer risk in Japanese men: A prospective study. Am J Epidemiol. 2008, 167, 71-77. DOI: 10.1093/aje/kwm249

114. Li, Q.; Kakizaki, M.; Kuriyama, S.; Sone, T.; Yan, H.; Nakaya, N.; Mastuda-Ohmori, K.; Tsuji, I., Green tea consumption and lung cancer risk: The Ohsaki study. Br J Cancer. 2008, 99, 1179-1184. DOI: 10.1038/sj.bjc.6604645

115. Lin, Y.; Kikuchi, S.; Tamakoshi, A.; Yagyu, K.; Obata, Y.; Kurosawa, M.; Inaba, Y.; Kawamura, T.; Motohashi, Y.; Ishibashi, T., et al., Green tea consumption and the risk of pancreatic cancer in Japanese adults. Pancreas. 2008, 37, 25-30. DOI: 10.1097/MPA.0b013e318160a5e2.

116. Liu, J.; Xing, J.; Fei, Y., Green tea (camellia sinensis) and cancer prevention: A systematic review of randomized trials and epidemiological studies. Chin Med. 2008, 22, 12. DOI: 10.1186/1749-8546-3-12

117. Luo, J.; Inoue, M.; Iwasaki, M.; Sasazuki, S.; Otani, T.; Ye, W.; Tsugane, S.; Group, J.S., Green tea and coffee intake and risk of pancreatic cancer in a large-scale, population-based cohort study in Japan (jphc study). Eur J Cancer Prev. 2007, 16, 542548. DOI: 10.1097/CEJ.0b013e32809b4d30

118. Myung, S.K.; Bae, W.K.; Oh, S.M.; Kim, Y.; Ju, W.; Sung, J.; Lee, Y.J.; Ko, J.A.; Song, J.I.; Choi, H.J., Green tea consumption and risk of stomach cancer: A meta-analysis of epidemiologic studies. Int J Cancer. 2009, 124, 670-677. DOI: 10.1002/ijc. 23880

119. Shimizu, M.; Fukutomi, Y.; Ninomiya, M.; Nagura, K.; Kato, T.; Araki, H.; Suganuma, M.; Fujiki, H.; Moriwaki, H., Green tea extracts for the prevention of metachronous colorectal adenomas: A pilot study. Cancer Epidemiol Biomarkers Prev. 2008, 17, 30203025. DOI: 10.1158/1055-9965.EPI-08-0528

120. Yang, G.; Shu, X.-O.; Li, H.; Chow, W.-H.; Ji, B.-T.; Zhang, X.; Gao, Y.-T.; Zheng, W., Prospective cohort study of green tea consumption and colorectal cancer risk in women. Cancer Epidemiol Biomarkers Prev 2007, 16, 1219-1223. DOI: 10.3945/ ajcn.111.031419 
121. Zhang, M.; Zhao, X.; Zhang, X.; D'Arcy, C.; Holman, J., Possible protective effect of green tea intake on risk of adult leukaemia. Br J Cancer. 2008 2008, 98, 168-170. DOI: 10.1038/sj.bjc.6604140

122. Zhou, Y.; Li, N.; Zhuang, W.; Liu, G.; Wu, T.; Yao, X.; Du, L.; Wei, M.; Wu, X., Green tea and gastric cancer risk: Meta-analysis of epidemiologic studies. Asia Pac J Clin Nutr. 2008, 17, 159-165.

123. Sun, C.L.; Yuan, J.M.; Koh, W.P.; Yu, M.C., Green tea, black tea and breast cancer risk: A meta-analysis of epidemiological studies. Carcinogenesis 2006, 27, 1310-1315. DOI: 10.1093/carcin/bgi276

124. Walch, N.; Chao, W.R.; Bensari, A.; Zaveri, N.T., Epigallocatechin gallate inhibits tumor growth in breast carcinoma cells (breast cancer). Anticancer Res. 2005, 25, 397-402.

125. Nakachi, K.; Suemasu, K.; Suga, K.; Takeo, T.; Imai, K.; Higashi, Y., Influence of drinking green tea on breast cancer malignancy among Japanese patients. Jpn J Cancer Res. 1998, 89, 254-261.

126. Yang, C.S.L., J. Yang, G.Y. ; Lu, G., Inhibition of lung tumorigenesis by tea. Exp Lung Res. 2005, 31, 135-144. DOI: 10.1080/01902140490495525.

127. Zhong, L.; Goldberg, M.S.; Gao, Y.T.; Hanley, J.A.; Parent, M.E.; Jin, F., A population-based case-control study of lung cancer and green tea consumption among women living in Shanghai, China. Epidemiology 2001, 12, 695-700.

128. Laurie, S.A.; Miller, V.A.; Grant, S.C.; Kris, M.G.; Ng, K.K., Phase i study of green tea extract in patients with advanced lung cancer. Cancer chemotherapy and pharmacology 2005, 55, 33-38. DOI: 10.1007/s00280-004-0859-1.

129. Clark, J.; You, M., Chemoprevention of lung cancer by tea. Molecular nutrition \& food research 2006, 50, 144-151. DOI: 10.1002/mnfr.200500135

130. Hoshiyama, Y.; Yatsuya, H.; Hayakawa, N.; Kawaguchi, T.; Sakata, K.; Tamakoshi, A.; Kondo, T.; Miura, Y.; Kikuchi, S.; Mizoue, T., et al., Green tea and stomach cancer -- a short review of prospective studies. Journal of Epidemiology 2005, 15, S109-S112. DOI: 10.2188/jea.15.S10.

131. Sun, C.-L.; Yuan, J.-M.; Lee, M.-J.; Yang, C.S.; Gao, Y.-T.; Ross, R.K.; Yu, M.C., Urinary tea polyphenols in relation to gastric and esophageal cancers a prospective study of men in Shanghai China. Carcinogenesis 2002, 23, 1497-1503. DOI: 10.1093/carcin/23.9.1497

132. Tsubono, Y.; Nishino, Y.; Komatsu, S.; Hsieh, C.; Kanemura, S.; Tsuji, I.; Nakatsuka, H.; Fukao, A.; Satoh, H.; Hisamichi, S., Green tea and the risk of gastric cancer in Japan. $N$ Engl J Med 2001, 344, 632-636. DOI: 10.1056/NEJM200103013440903

133. Jian, L.; Xie, L.P.; Lee, A.H.; Binns, C.W., Protective effect of green tea against prostate cancer: A case-control study in southeast China. International journal of cancer. Journal international du cancer 2004, 108, 130-135. DOI: 10.1002/ijc. 11550

134. Siddiqui, I.A.; Adhami, V.M.; Saleem, M.; Mukhtar, H., Beneficial effects of tea and its polyphenols against prostate cancer. Molecular nutrition \& food research $\mathbf{2 0 0 6}$, 50, 130-143. DOI: 10.1002/mnfr.200500113

135. Ellison, L.F., Tea and other beverage consumption and prostate cancer risk: A Canadian retrospective cohort study. Eur $J$ Cancer Prev. 2000, 9, 125-130.

136. Adhami, V.M.; Ahmad, N.; Mukhtar, H., Molecular targets for green tea in prostate cancer prevention. J Nutr. 2003, 133, 2417S2424S.

137. Bianchi, G.D.; Cerhan, J.R.; Parker, A.S.; Putnam, S.D.; See, W.A.; Lynch, C.F.; Cantor, K.P., Tea consumption and risk of bladder and kidney cancers in a populationbased case-control study. American Journal of Epidemiology 2000, 151, 377-383.

138. Jung, Y.; Kim, M.; Shin, B.; Chay, K.; Ahn, B.; Liu, W.; Bucana, C.; Gallick, G., EGCG, a major component of green tea, inhibits tumour growth by inhibiting vegf induction in human colon carcinoma cells. British Journal of Cancer 2001, 84, 844-850. DOI: $\underline{10.1054 / \mathrm{bjoc} .2000 .1691}$ 
139. Sun, C.L.; Yuan, J.M.; Koh, W.P.; Yu, M.C., Green tea, black tea and colorectal cancer risk: A meta-analysis of epidemiologic studies. Carcinogenesis 2006, 27, 13011309. DOI: $10.1093 / \mathrm{carcin} / \mathrm{bg} 1024$

140. Gao, Y.T.; McLaughlin, J.K.; Blot, W.J.; Ji, B.T.; Dai, Q.; Fraumeni, J.F., Reduced risk of esophageal cancer associated with green tea consumption. J Natl Cancer Inst. 1994, 86, 855-858. DOI: 10.1093/jnci/86.11.855

141. Hakim, I.A.; Harris, R.B.; Weisgerber, U.M., Tea intake and squamous cell carcinoma of the skin influence of type of tea beverages. Cancer Epidemiol Biomarkers Prev 2000, 9, 727-731.

142. Steptoe, A.; Gibson, E.L.; Vounonvirta, R.; Williams, E.D.; Hamer, M.; Rycroft, J.A.; Erusalimsky, J.D.; Wardle, J., The effects of tea on psychophysiological stress responsivity and post-stress recovery: A randomised double-blind trial. Psychopharmacology 2007, 190, 81-89. DOI: $10.1007 / \mathrm{s} 00213-006-0573-2$

143. Ji, B.-T.; Chow, W.-H.; Hsing, A.; McLaughlin, J.K.; Dai, Q.; Gao, Y.-T.; Blot, W.J.; Fraumeni, J.F., Green tea consumption and the risk of pancreatic and colorectal cancers. Int. J. Cancer 1997, 70, 255-258. DOI: $10.1093 /$ carcin/bgr186

144. Hintikka, J.; Tolmunen, T.; Honkalampi, K.; Haatainen, K.; Koivumaa-Honkanen, H.; Tanskanen, A.; Viinamäki, H., Daily tea drinking is associated with a low level of depressive symptoms in the finnish general population. Eur J Epidemiol. 2005, 20, 359363. DOI: 10.1007/s10654-005-0148-2

145. Niu, K.; Hozawa, A.; Kuriyama, S.; Ebihara, S.; Guo, H.; Nakaya, N.; Ohmori-Matsuda, K.; Takahashi, H.; Masamune, Y.; Asada, M., et al., Green tea consumption is associated with depressive symptoms in the elderly. Am J Clin Nutr. 2009, 90, 16151622. DOI: 10.3945/ajen.2009.28216

145.a Williamson, M.; McCormick, T.; Nance C.; Shearer W. Epigallocatechin gallate, the main polyphenols in green tea, binds to the T-cell receptor, CD-4: Potential for HIV-1 therapy. J.Allergy Clin. Immunol. 2006, 118, 1369-1374. DOI: 10.1016/j.jaci.2006.08.016.
146. Kuriyama, S.; Hozawa, A.; Ohmori, K.; Shimazu, T.; Matsui, T.; Ebihara, S.; Awata, S.; Nagatomi, R.; Arai, H.; Tsuji, I., Green tea consumption and cognitive function: A cross-sectional study from the tsurugaya project 1. Am J Clin Nutr. 2006, 83, 355361.

147. Tsushida, T.; Muroi, T.; Omori, M.; Okamoto, J., Production of a new type tea containing a high level of g-aminobutiric acid. Nippon Nogeikagaku Kaishi 1987, 6, 817-822.

148. Ou, A.M.S., Gaba to reduce blood pressure. Yuan Chi Publisher Co. : Taipei, Taiwan, 2002.

149. De Feudis, F.V., Gamma-aminobutyric acid and cardiovascular function. Experientia 1983, 39, 845-849. DOI: 10.1007/BF01990401

150. F. Petty., Gaba and mood disorders: A brief review and hypothesis. . Journal of Affective Disorders 1995, 34, 275-286. DOI: 10.1016/0165-0327(95)00025-I

151. Shiah, I.S.; Yatham, L.N., Gaba function in mood disorders: An update and critical review. Life sciences 1998, 63, 1289-1303. DOI: 10.1016/S0024-3205(98)00241-0

152. Petty, F.; Fulton, M.; Moeller, F.G., Plasma gamma-aminobutyric acid (gaba) is low in alcoholics. Psychopharmacology Bulletin 1993, 29, 277-281.

153. Coffman, J.A.; Petty, F., Plasma gaba level in chronic alcoholics. The American Journal of Psyhiatry 1985, 142, 1204-1205

154. Petty, F.; Sherman, A.D., Plasma gaba levels in psychiatric illness. Journal of Affective Disorders 1984, 6, 131-138. DOI: 10.1016/0165-0327(84)90018-1

155. Ou, A.S.M.; Tsoi, Y.-S.; Wang, H.F., Biological functions and manufacturing of gaba tea. In: "Tea products". CRC Press 2008.

156. Kayahara, H.; Sugiura, T., Recent studies on biological function of gaba on improvements of hypertension and brain function. Up-toDate Food Processing 2001, 36, 4-6. DOI: 10.1016/i.foodchem.2005.02.046

157. Wang, H.F.; Tsai, Y.S.; Lin, M.l.; Ou, A.M., Comparison of bioactive components in 
gaba tes and green tea produced in taiwan.

Food Chem. 2006, 96, 648-653. DOI: 10.1016/j.foodchem.2005.02.046

158. Federico, A.; Tiso, A.; Loguercio, C., A case of hepatotoxicity caused by green tea. Free Radic Biol Med. 2007, 43, 474. DOI:10.1016/j.freeradbiomed.2007.05.010

159. Frank, J.; George, T.W.; Lodge, J.K.; Rodriguez-Mateos, A.M.; Spencer, J.P.; Minihane, A.; Rimbach, G., Daily consumption of an aqueous green tea extract supplement does not impair liver function or alter cardiovascular disease risk biomarkers in healthy men. $J$ Nutr. 2009, 139, 58-62. DOI: 10.3945/jn.108.096412.

160. Narotzki, B.; Reznick, A.Z.; Aizenbud, D.; Levy, Y., Green tea: A promising natural product in oral health. Arch Oral Biol. 2012, 57 , 429-435.

DOI: 10.1016/j.archoralbio.2011.11.017

161. Shen, C.L.; Yeh, J.K.; Cao, J.J.; Chyu, M.C.; Wang, J.S., Green tea and bone health:
Evidence from laboratory studies. Pharmacol Res. 2011, 64, 155-161. DOI: 10.1016/j.phrs.2011.03.012

162. Hodgson, J.M.; Croft, K.D., Tea flavonoids and cardiovascular health. Mol Aspects Med. 2010, 31, 495-502. DOI: 10.1016/j.mam.2010.09.004

163. Yang, C.S.; Lambert, J., Research on tea and health. Pharmacol Res. 2011, 64, 85-86.

164. Hossein, O.; Ahmad, M.; Shayan, G. Biochemical and biological properties of polyphenolic catechins in green tea extract for health benefits. Clin Biochem 2011, 44, S338. DOI: 